\title{
Development of Modern Physics Learning Devices Using Inquiry Learning Model Assisted with Virtual Media to Improve Student Cognitive Learning Result
}

\author{
Aris Doyan* \\ Master of Science Education Study Program \\ University of Mataram \\ West Nusa Tenggara, Indonesia \\ *aris_doyan@unram.ac.id
}

\author{
Susilawati, Muh. Makhrus, Zamrizal W. \\ Physics Education Study Program \\ University of Mataram \\ West Nusa Tenggara, Indonesia \\ susilawatihambali@unram.ac.id
}

\begin{abstract}
This study aims to determine the effectiveness of developing modern physics learning tools with a guided inquiry learning model assisted by PhET virtual media on the cognitive learning outcomes of students. This study uses a Four D-Model development model. The subjects in this study were undergraduate students who were taking modern physics courses. The results of the development in this study are modern physics learning tools in the form of Semester Program Plan, Student Worksheets, teaching materials, and evaluation instruments. To determine the effectiveness of the product, the students' significant learning outcomes were analyzed using $\mathbf{N}$ gain analysis. The results of the analysis show that the development of modern physics learning tools using guided inquiry learning with virtual media PhET is effective for improving student cognitive learning outcomes with a gain value of 0.7 in the moderate category.
\end{abstract}

Keywords-modern physics learning tools, guided inquiry, virtual media, student cognitive learning outcomes

\section{INTRODUCTION}

Modern physics is a branch of science from physics. Modern physics is a branch of physics that deals with physical phenomena from a modern point of view in order to explain phenomena physics that cannot be explained classically. Modern physics is one of the compulsory courses that students of physics education study program at the University of Taram must take. Modern physics lectures will run smoothly if good planning is done according to needs. Good quality lectures will be achieved if good learning tools are available. States that improving the quality of learning for a lecturer is very strategic, because the lecturer serves as the spearhead of the change from not being able to become capable, from not mastering to mastering, and from not understanding to understanding. In addition, states that student factors, available facilities, tools, and media, as well as environmental factors can also affect the learning process. What happens in the field related to the modern physics lecture process shows that the learning outcomes of students are still low. This is because students still have difficulty understanding the concepts that exist in modern physics courses that seem abstract [1].

One learning model that can provide opportunities for students to understand the concepts of modern physics is the guided learning model. Inquiry-based learning includes practices that prioritize scientific concepts and processes. When learning with the inquiry model, students engage in scientifically oriented questions, prioritize evidence to develop and evaluate explanations of scientific questions, formulate alternative explanations, communicate and provide mutual input [2]. Inquiry-based learning provides opportunities to interact with instructors, other students, and the material is able to provide a deeper understanding of new knowledge so that it can develop higher-order thinking skills [3]. Inquiry learning is designed to invite students directly into the scientific process in a relatively short time. Implementation of the guided inquiry learning model emphasizes the maximum activity of students to train critical thinking skills so that they can improve student learning outcomes.

In addition to the application of appropriate learning models, another factor that affects the learning process is the use of appropriate learning media. Even more so for modern abstract physics material. The media used can be real media and virtual media. For modern physics learning, virtual media is needed because the material is focused on physical phenomena that cannot be observed directly. The use of technology in science learning provides ample opportunities for educational development. Effective technology can also strengthen and enrich student learning in an interactive manner that encourages creativity through visualization, simulation and modeling [4]. One of the virtual media that is currently available and can be used as a media for learning media for virtual laboratory production from PhET Colorado. PhET has theoretical and experimental simulations that actively involve the user. PhET simulation can display a physics animation that is abstract or cannot be seen by the naked eye such as: atoms, electrons, photons and magnetic fields. Besides being able to 
build concepts, PhET can also be used to bring up science process skills.

The application of the PhET virtual media assisted inquiry learning model can help lecturers to connect the material taught with the real-world situation of students and also encourage students to make connections between their knowledge and its application in everyday life. So that students become more active in the learning process and can understand the concept well.

\section{MethoDS}

This research is a research and development that uses the Four D-Model development model to develop modern physics learning tools with a guided inquiry learning model assisted by PhET virtual media. This research was conducted in the Physics Education Study Program, FKIP UNRAM. To determine the effectiveness of the resulting product, a trial application was carried out in the learning process. The trial design used was pre-experimental designs with one group pretest-posttest design. The sample used was all undergraduate students in one class who were the objects of the study, which means that the sample was not chosen randomly. In this design, there is a pre-test before treatment and a post-test after being given learning with guided inquiry learning model using PHET virtual media. The improvement of students' cognitive learning outcomes was analyzed using the N-Gain test. The N-Gain test is carried out using the formula:

$$
g=\frac{S_{\text {post }}-S_{\text {pre }}}{S_{\text {max }}-S_{\text {pre }}} \times 100 \%
$$

Description:

$$
\begin{array}{ll}
\mathrm{g} & \text { : gain normalized ( } \mathrm{N}-\text { gain), } \\
\mathrm{S}_{\max } & \text { : maximum score (ideal), } \\
\text { Spost } & \text { : final test score, } \\
\text { Spre } & \text { : initial test scores. }
\end{array}
$$

The criteria for improving student learning outcomes are given in the table 1 below:

TABLE I. CRITERIA FOR N-GAIN IMPROVEMENT

\begin{tabular}{|l|l|}
\hline \multicolumn{1}{|c|}{ Value of N-Gain } & \multicolumn{1}{c|}{ Category } \\
\hline $0.7<\mathrm{N}$-gain & High \\
\hline $0.3 \leq \mathrm{N}$-gain $\leq 0.7$ & Middle \\
\hline $\mathrm{N}$-gain $<0.3$ & Low \\
\hline
\end{tabular}

\section{RESULTS AND DISCUSSION}

The results of the feasibility test for modern physics learning devices with the guided inquiry learning model assisted by $\mathrm{PhET}$ virtual media show that the devices developed in the form of semester program plans, student work throws, teaching materials, and evaluation instruments have good validity, are practical to use, and are effective. To find out the effectiveness of the devices developed to improve the cognitive learning outcomes of students, the learning tools were tried on undergraduate students who were taking modern physics courses. The description of student cognitive learning outcomes in the form of pre-test and post-test in modern physics courses is shown in the table 2 below.

TABLE II. DESCRIPTION OF PRE-TEST AND Post-TeST VALUE

\begin{tabular}{|l|l|l|l|l|l|}
\hline \multicolumn{1}{|c|}{ Aspect } & $\mathbf{N}$ & $\begin{array}{c}\text { Lowest } \\
\text { Value }\end{array}$ & $\begin{array}{c}\text { Highest } \\
\text { Value }\end{array}$ & Average & $\begin{array}{c}\text { Standard } \\
\text { Deviation }\end{array}$ \\
\hline Pre-test & 20 & 15 & 55 & 44.30 & 9.34 \\
\hline Post-test & 20 & 58 & 91 & 81.05 & 8.02 \\
\hline
\end{tabular}

The results of each respondent's gain analysis are shown in the Fig.1, and the $\mathrm{N}$-gain value of each cognitive aspect, namely knowledge $(\mathrm{C} 1)$, understanding $(\mathrm{C} 2)$, application $(\mathrm{C} 3)$, analysis (C4), synthesis (C5), and evaluation (C6) is shown in the Fig. 2.

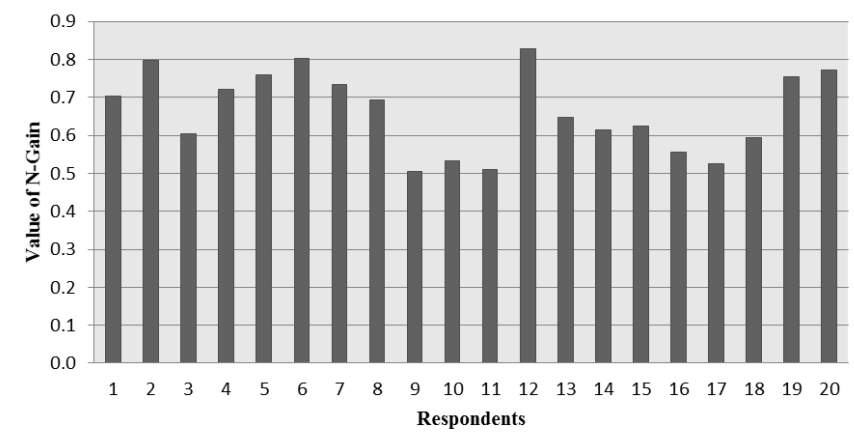

Fig. 1. Graph of the N-gain value of each respondent.

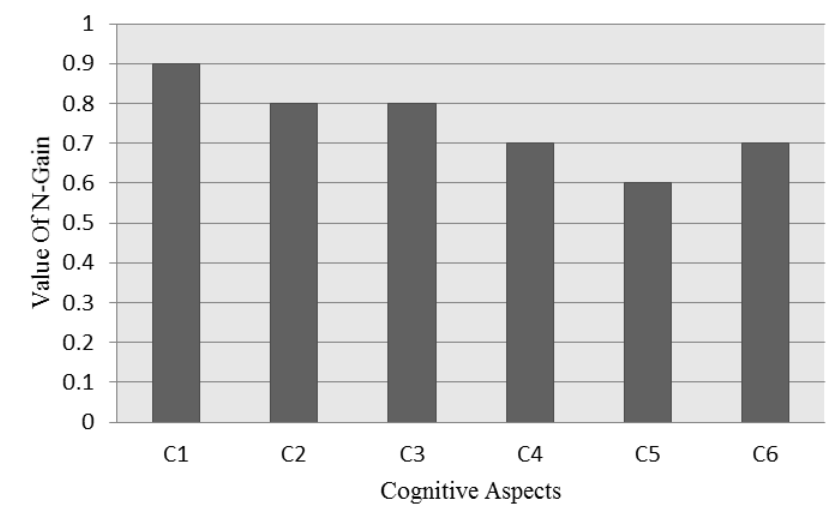

Fig. 2. Graph of the N-gain value of cognitive aspects.

Based on Fig.1, it can be explained that the average category of increase in the cognitive score of students is "moderate", although there are some students who experience an increase in the "high" category. This shows that modern physics learning tools based on inquiry learning with $\mathrm{PhET}$ virtual media can improve student cognitive learning outcomes. 
Based on Fig. 2, it can be said that the category of increasing the knowledge aspect is "high", the understanding aspect is "high, the application aspect is" high ", the analysis aspect is" medium ", the synthesis aspect is" low ", and the evaluation aspect is" moderate ". Overall, it can be seen that the cognitive aspect improvement category decreased from $\mathrm{C} 1$ to C6. This is because the difficulty level has increased from $\mathrm{C} 1$ to C6. The category of improvement in the synthesis aspect is the lowest. This happens because in this aspect, students are required to form new equations from other quantities related to the photo-electric effect material, but these quantities are not explained directly and are not available on the PhET media used. So that students must be able to independently find the relationship of other quantities to the general quantities contained in the photo electric effect equation. Aspects C1, C2, and C3 have a good increase. This is because the level of difficulty in this aspect is lower and the material for mastering this aspect is contained in PhET virtual media. Broadly speaking, all aspects have increased. This is in line with previous research related to the application of virtual media assisted learning models. The application of virtual media assisted learning models can improve the ability of every cognitive aspect of learning. Increasing students' mastery of concepts is an influence during the learning process [5].

The application of the PhET virtual media assisted inquiry learning model is very helpful in providing understanding that modern physics material is provided. This is indicated by the increase in cognitive learning outcomes of students who are given inquiry learning assisted by virtual media PhET obtaining "moderate" criteria. Inquiry learning is a learning activity that maximally involves all the abilities of students to search and investigate systematically, critically, and logically. So that students can find their own knowledge. Inquiry provides opportunities for students to solve problems critically, analytically, and scientifically by using certain steps towards convincing conclusions because they are supported by data or reality. So that inquiry learning does not only develop knowledge, but also a positive attitude and self-confidence. Inquiry is able to develop students' beliefs to improve science process skills in the form of discussion and collaboration so that students are able to better understand the subject matter [6].

The use of PhET virtual media is also very helpful in the learning process in accordance with the nature of learning physics. Some of the research results that have been conducted state that the learning outcomes of students who use learning tools that are synergized with PheT virtual laboratory media are better than students who do not use PheT virtual lab media. One way to improve students' mastery of concepts is to use an inquiry learning model with interactive computer simulation. By using a computer simulation-assisted inquiry learning model, students are better able to develop science process skills in order to gain mastery of concepts. By using simulations, students have the opportunity to conduct experiments to find out the relationships between quantities so that they can better understand the material [7].
The use of PhET media allows students to do experiments independently via a computer or cellphone. Independent experiments carried out by students are still based on the references given by the educator in the form of student worksheets. The worksheets used are adjusted to the inquiry learning syntax. The use of inquiry-based student worksheets is able to direct students to conduct experiments according to the expected goals so that students gain correct knowledge of the material being taught. From other research that has been done, it can be concluded that learning using a guided inquiry model with the existence of student worksheets can help students produce real-world competencies, namely good attitudes towards students. With guided questions, the learning model assisted by student worksheets can increase discipline, responsibility, and confidence in experiments. A confident attitude will make students dare to do experiments and determine the results of their own experiments. This attitude is a scientific attitude that students must have in the learning process so that they are able to obtain meaningful knowledge [8].

PhET simulations are very effective at helping students build understanding and intuition for abstract phenomena. PhET simulation can build and practice science process skills, thereby increasing understanding of concepts [9]. Apart from building students' understanding and intuition, PhET simulations can also help students learn independently. Students become less dependent on teacher explanations. Students become enthusiastic in learning science; they can handle themselves even if the teacher is out. They become confident and pass the subject matter afterwards using virtual laboratory activities [10].

Based on the results of the research above, it can be concluded that modern physics learning tools based on inquiry learning are effective in improving the cognitive learning outcomes of students. Syntax for inquiry learning models that support the growth and development of science process skills which are the essence of science learning. In addition to the learning syntax, the use of PhET virtual media provides solutions to abstract experiments. Inquiry learning with experimental activities is an ideal to help improve students thinking skills. Increasing the thinking skills of students will have a positive effect on learning outcomes, especially for abstract modern physics material. By using PhET media, students are helped in the problem solving process. For example in the photo electric effect material. By using PhET, students can observe the effect of electric photos directly and try to do experiments to find out the quantities that affect and the relationship of each quantity. This of course will greatly help students to better understand the material. In addition, the use of virtual media in particular for experiments will help create a positive and fun learning atmosphere. In addition, it will also increase student motivation and interest in learning [11].

Based on the description of the results and discussion, modern physics learning tools based on inquiry learning with virtual PhET media can be included in the category of good 
and effective learning tools. So that it can be recommended to be used by educators to be a solution to modern physics learning problems so far.

\section{CONCLUSION}

Modern physics learning tools with an inquiry learning model consisting of semester program plans, student worksheets, teaching materials, and evaluation instruments have good validity and are practical to use because the device is integrated with PhET virtual media. Modern physics learning devices with inquiry learning models with virtual media PhET are effective in improving student cognitive learning outcomes. This is indicated by the average increase in cognitive scores that fall into the "medium" category.

\section{ACKNOWLEDGMENT}

Thank you to the research team and to the Head of physics education department Mataram University for facilitating the implementation of this research to completion as well as all those who have helped in this research.

\section{REFERENCES}

[1] B. Munthe, Learning Design. Yogyakarta: Publisher Pustaka Insan Madanai, 2009.

[2] National Research Council, Inquiry and the national science education standards. Washington, DC: National Academy Press, 2000.
[3] R.D. Anderson, "Reforming science teaching: What research says about inquiry," Journal of Science Teacher Education, vol. 13, no. (1), pp. 1$12,2002$.

[4] R. Repnik and V. Grubelnik, "E-Learning Materials for 3rd Grade of Primary School-Physics," International Journal of Emerging Technologies in Learning (iJET), vol. 5, no. (2), p. 43, 2010.

[5] S.M. Dewi, G. Gunawan, A. Harjono, S. Susilawati, and L. Herayanti, "Generative learning models assisted by virtual laboratory to improve mastery of student physics concept," Journal of Physics: Conference Series, vol. 1521, no. 2, p. 022013, 2020.

[6] N. Tatar, "Inquiry - Based Science Laboratories : An Analysis Of Preservice Teacher's About Learning Science Through Inquiry Their Performance," Journal of Baltic Science Education, vol. 11, no. 3, 2012.

[7] Supriyatman and Sokarno, "Improving Science Process Skills (SPS) Science Concepts Mastery (SCM) Prospective Student Teachers Through Inquiry Learning Instruction Model By Using Interactive Computer Simulation," International Journal of Science and Research (IJSR), vol. 2, no. 3, 2014.

[8] Laila and Lufri, "The Influence of Guided Inquiry Learning Model with LKPD Assistance on Attitude Competencies of Class XI Students of SMAN 1 Sungayang," International Journal of Progressive Sciences and Technologies (IJPSAT), vol. 15, no. 2, pp. 171-175, July 2019.

[9] N.D. Finkelstein, W.K. Adams, C.J. Keller, P.B. Kohl, K.K. Perkins, N.S. Podolefsky, ... and R. LeMaster, "When learning about the real world is better done virtually: A study of substituting computer simulations for laboratory equipment," Physical review special topicsphysics education research, vol. 1, no. (1), p. 010103, 2005.

[10] J.A. Taguchi, "Learning Outcomes of Studentsin Traditional and Virtual Laboratory Instruction in Science," International Journal of Science and Research (IJSR), vol. 8, no. 5, 2019.

[11] Topalsan, "Development of Scientific Inquiry Skills Of Science Teaching Through Argument-Focused Virtual Laboratory Applications," Journal of Baltic Science Education, vol. 19, no. 4, 2020. 